\title{
Allometric scaling of seagrass form and productivity
}

\author{
Carlos M. Duarte \\ Centro de Estudios Avanzados de Blanes, Camino de Santa Bárbara, E-17300 Blanes, Gerona, Spain
}

\begin{abstract}
The implications of differences in plant size for seagrass productivity were examined based on an extensive compilation of data on architecture and growth of seagrass species. The analysis revealed strong allometric relationships between the size of different components, particularly a close scaling of the size of leaves, shoots, and fruits to rhizome diameter, as well as strong relationships between shoot size and the dynamics (e.g. turnover rate, plastochrone interval, and longevity) of seagrass leaves and rhizomes of different species. The decrease in rhizome elongation rates and leaf turnover rates with increasing seagrass size demonstrates the importance of architecture for seagrass productivity, and also provides explanations for the different ecological roles of small, colonizing species, and large, climax seagrass species. In addition, these results demonstrate that while habitat conditions have important influences on seagrass productivity, differences in size may explain the vast range of turnover times, plastochrone intervals, and module longevities, encountered among seagrass species
\end{abstract}

\section{INTRODUCTION}

Seagrasses are characterized by a relative taxonomic and architectural uniformity, and are represented by few (abolit 50 species distributed in 12 genera) species (Den Hartog 1970, Stevenson 1988). Seagrasses grow by the reiteration of modules (rhizome internodes, leaf clusters, and roots; cf. Tomlinson 1974). Yet, the biomass and turnover rates of different seagrass species differ by orders of magnitude (cf. Stevenson 1988).

Attempts to explain differences in seagrass biomass and production and, thus, their importance in shallow sandy ecosystems, have focused primarily on the influence of habitat conditions, particularly temperature and light (cf. Hillman et al. 1989) and, more recently, nutrient availability (Short 1987, Short et al. 1990, Perez et al. 1991). However, fast-growing, colonizing species are often small (e.g. Halophila spp.), whereas slow-growing, 'climax' species are often large (e.g. Enhalus acoroides and Posidonia spp.; cf. Den Hartog 1977. Hillman et al. 1989), suggesting that differences in plant size may help to explain productivity differences among seagrass species.

Here I used an extensive compilation of data on architecture and growth of different seagrass species to examine the implications of differences in module size to account for differences in productivity among seagrass species. To achieve this goal I first examined the (interspecific) allometric relationships among the size of different seagrass modules, and then assessed the implications of differences in module size for seagrass dynamics.

\section{METHODS}

I searched the literature for data on seagrass module size (rhizome diameter and internodal length, shoot weight, leaf area, and fruit size) and dynamics [longevity, plastochrone intervals (i.e. the time elapsed between production of consecutive modules), and growth; Table 1]. I also report data for Ruppia maritima L., an angiosperm species similar in architecture to seagrasses and also abundant in coastal zones throughout the world. I used average values when possible, and when data were given as ranges, I used the arithmetic and geometric midpoint for ranges smaller and greater than an order of magnitude, respectively. Because the architecture and dynamics of individual seagrass populations may reflect habitat conditions rather than characteristic values for the species, the variables in the data set compiled were averaged by species, and these average values were then used to represent the architecture and productivity of each seagrass species in the analyses. Thus, the units ana- 
Table 1. Sources of data on architectural and dynamic characteristics of different seagrass species, and on Ruppia maritima, an angiosperm species abundant in coastal areas

\begin{tabular}{|c|c|c|c|}
\hline Species & Source & Species & Source \\
\hline \multirow[t]{4}{*}{ Amphibolis antarctica } & Den Hartog $(1970)$ & Phyllospadix iwatensis & Den Hartog (1970) \\
\hline & Walker \& McComb (1988) & Phyllospadix japonicus & Den Hartog (1970) \\
\hline & Hillman et al. (1989) & Phyllospadix serrulatus & Den Hartog (1970) \\
\hline & Walker (1989) & Phyllospadix torreyi & Den Hartog (1970) \\
\hline \multirow[t]{2}{*}{ Amphibolis griffithii } & Den Hartog $(1970)$ & & Stewart (1989) \\
\hline & Hillman et al. (1989) & Phyllospadix scouleri & Den Hartog (1970) \\
\hline Cymodocea angostata & Den Hartog $(1970)$ & Posidonia australis & Den Hartog (1970) \\
\hline Cymodocea nodosa & $\begin{array}{l}\text { Den Hartog (1970) } \\
\text { Cayé \& Meinesz (1985) } \\
\text { Perez (1989) } \\
\text { Peduzzi \& Vukovis (1990) } \\
\text { Duarte (unpubl. results) }\end{array}$ & & $\begin{array}{l}\text { Larkum (1976) } \\
\text { Kirkman \& Reid (1979) } \\
\text { West \& Larkum (1979) } \\
\text { Silverstein et al. (1986) } \\
\text { Walker \& McComb (1988) }\end{array}$ \\
\hline Cymodocea rotundata & $\begin{array}{l}\text { Ogden \& Ogden (1982) } \\
\text { Brouns (1987) }\end{array}$ & & $\begin{array}{l}\text { Clarke \& Kirkman (1989) } \\
\text { Hillman et al. (1989) } \\
\text { West et al. (1989) }\end{array}$ \\
\hline Cymodocea rotundifolia & Den Hartog $(1970)$ & & West $(1990)$ \\
\hline Cymodocea serrulata & $\begin{array}{l}\text { Den Hartog (1970) } \\
\text { Ogden \& Ogden (1982) } \\
\text { Brouns (1987) }\end{array}$ & Posidonia oceanica & $\begin{array}{l}\text { Den Hartog }(1970) \\
\text { Ott }(1979) \\
\text { Ott }(1980)\end{array}$ \\
\hline Enhalus acoroides & $\begin{array}{l}\text { Den Hartog (1970) } \\
\text { Johnstone (1979) } \\
\text { Ogden \& Ogden (1982) } \\
\text { Brouns \& Heijs (1986) } \\
\text { Estacion \& Fortes (1988) }\end{array}$ & & $\begin{array}{l}\text { Bedhomme (1981) } \\
\text { Thelin \& Bouderesque (1983) } \\
\text { Bay (1984) } \\
\text { Bouderesque et al. (1984) } \\
\text { Pirc (1984) }\end{array}$ \\
\hline Halodule beaudettei & Den Hartog $(1970)$ & & Wittmann (1984) \\
\hline Halodule bermudensis & Den Hartog (1970) & & Buia et al. (1985) \\
\hline Halodule pinifolia & Den Hartog $(1970)$ & & $\begin{array}{l}\text { Romero-Martinengo (1985) } \\
\text { Pergent \& Pergent-Martini (1990) }\end{array}$ \\
\hline Halodule uninervis & $\begin{array}{l}\text { Den Hartog }(1970) \\
\text { Ogden \& Ogden (1982) } \\
\text { Brouns (1987) }\end{array}$ & & $\begin{array}{l}\text { Semround et al. (1990) } \\
\text { Duarte (unpubl. results) }\end{array}$ \\
\hline & $\begin{array}{l}\text { Brouns }(1987) \\
\text { Den Hartog }(1970)\end{array}$ & Posidonia ostenfeldii & Den Hartog (1970) \\
\hline Halodule wrighw & Vinstein (1982) & Ruppia marituma & Bigley \& Harrison (1986) \\
\hline & Eleuterius (1987) & Syringodium filiforme & Den Hartog (1970) \\
\hline Halophila baillonis & Den Hartog $(1970)$ & & Ogden \& Ogden (1982) \\
\hline Halophila beccarii & Den Hartog $(1970)$ & & $\begin{array}{l}\text { Fry (1983) } \\
\text { Barber \& Beherens (1985) }\end{array}$ \\
\hline Halophila decipiens & $\begin{array}{l}\text { Den Hartog (1970) } \\
\text { Gil-Rodriguez \& Cruz-Simó (1982) } \\
\text { Josselyn et al. (1986) }\end{array}$ & & $\begin{array}{l}\text { Eleuterius (1987) } \\
\text { Williams (1987) } \\
\text { Fry \& Virnstein (1988) }\end{array}$ \\
\hline Halophila engelmanni & $\begin{array}{l}\text { Kenworthy et al. (1989) } \\
\text { Den Hartog }(1970)\end{array}$ & Syringodium isoetifolium & $\begin{array}{l}\text { Den Hartog }(1970) \\
\text { Brouns }(1987)\end{array}$ \\
\hline Halophila hawaiiana & Herbert (1986) & & Clarke \& Kirkman (1989) \\
\hline Halophila ovalis & $\begin{array}{l}\text { Den Hartog (1970) } \\
\text { Ogden \& Ogden (1982) } \\
\text { Brouns (1987) } \\
\text { Clarke \& Kirkman (1989) }\end{array}$ & Thalassia hemprichij & $\begin{array}{l}\text { Den Hartog }(1970) \\
\text { Ogden \& Ogden (1982) } \\
\text { Brouns (1985) } \\
\text { Brouns }(1987)\end{array}$ \\
\hline Halophila ovata & Den Hartog (1970) & Thalassia testudinum & $\begin{array}{l}\text { Tomlinson \& Vargo (1966) } \\
\text { Den Hartog }(1970)\end{array}$ \\
\hline Halophila spinulosa & Den Hartog (1970) & & Patriquin (1973) \\
\hline Halophila stipulacea & $\begin{array}{l}\text { Den Hartog }(1970) \\
\text { Hulings }(1979) \\
\text { Wahbeh }(1984)\end{array}$ & & $\begin{array}{l}\text { Taylor et al. (1973) } \\
\text { Buesa (1974) } \\
\text { Zieman (1975) }\end{array}$ \\
\hline Heterozostera tasmanica & $\begin{array}{l}\text { Den Hartog (1970) } \\
\text { Bulthuis (1983) } \\
\text { Bulthuis \& Woelkerling (1983) } \\
\text { Phillips et al. (1983) } \\
\text { Clarke \& Kirkman (1989) } \\
\text { Hillman et al. (1989) }\end{array}$ & & $\begin{array}{l}\text { Zieman et al. (1984) } \\
\text { Barber \& Beherens (1985) } \\
\text { Iverson \& Bittaker (1986) } \\
\text { Eleuterius (1987) } \\
\text { Williams (1987) } \\
\text { Dawes \& Tomasko (1988) }\end{array}$ \\
\hline
\end{tabular}


Table 1 (continued)

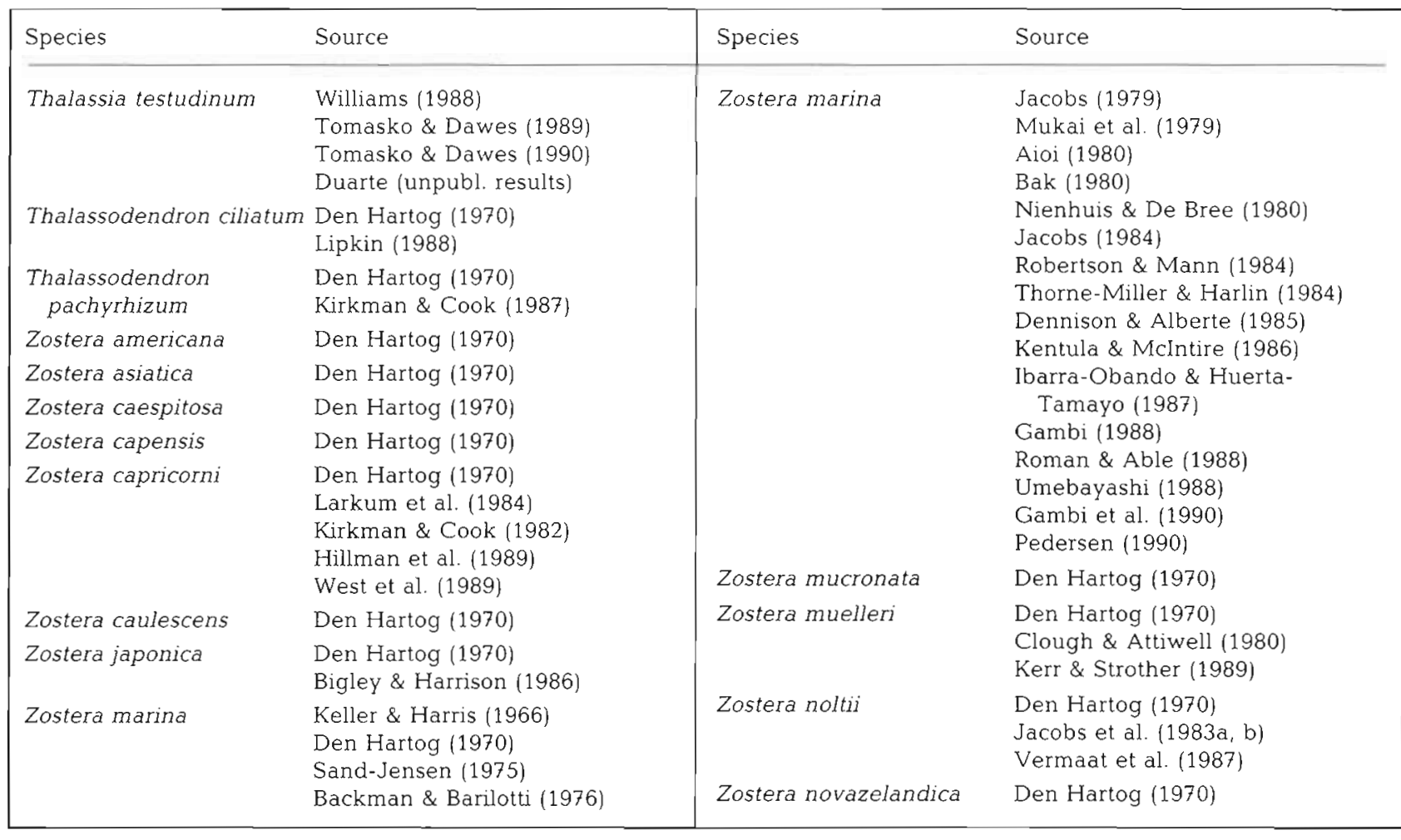

lyzed were seagrass species and not seagrass stands Relationships among these variables were then described using reduced major axis regression analyses (Till 1974) to prevent bias in regression coefficients derived from error in the independent and dependent variables (LaBarbera 1989). The allometric relationships between the size of plant parts and between plant size and dynamics were described by fitting the equation

$$
Y=a X^{b}
$$

which has been used extensively to describe allometric relationships between organismal parts, and to scale plant growth to size (Huxley 1932, LaBarbera 1989). The strength of the relationships obtained was described by the coefficient of determination $\left(R^{2}\right)$, and their precision was described by the standard error of the regression estimate.

The importance of among- versus within-species variability in seagrass architecture and dynamics was assessed by comparing the among-and within-species coefficient of variation for those variables where sufficient information was available to calculate both. Within-species variability reflects both differences among populations of individual seagrass species and seasonal variability in the properties examined, since average annual values were not available for all species.

\section{RESULTS}

Seagrass species differ widely in module size (Table 2), among-species variability being much greater than that within species, except for differences in the number of leaves per shoot (or leaf cluster) and, to a lesser extent, the length of rhizome internodes, where within-species variability was comparable to amongspecies differences (Table 2). The dynamic properties of seagrasses also ranged widely among species, except for leaf elongation rates, where variability within species was quite considerable and comparable to that among species (Table 2).

\section{Allometric relationships between seagrass modules}

The sizes of leaves, shoots, and fruits of different seagrass species were strongly related to the diameter of their rhizomes (Eqs. 1 to 3 in Table 3; Fig. 1). The rate of increase in size with increasing rhizome diameter was greatest for fruit volume (slope $=2.91$ ), intermediate for shoot weight (slope $=2.57$ ), and smallest for leaf size (slope $=2.17 ;$ Table 3 ). The number of shoots produced per rhizome internode, which influences the spacing in between shoots, was also strongly, positively related to rhizome diameter $(\mathrm{r}=0.78, \mathrm{p}<0.001)$, indicating that shoots of seagrass species with thick diameters are 


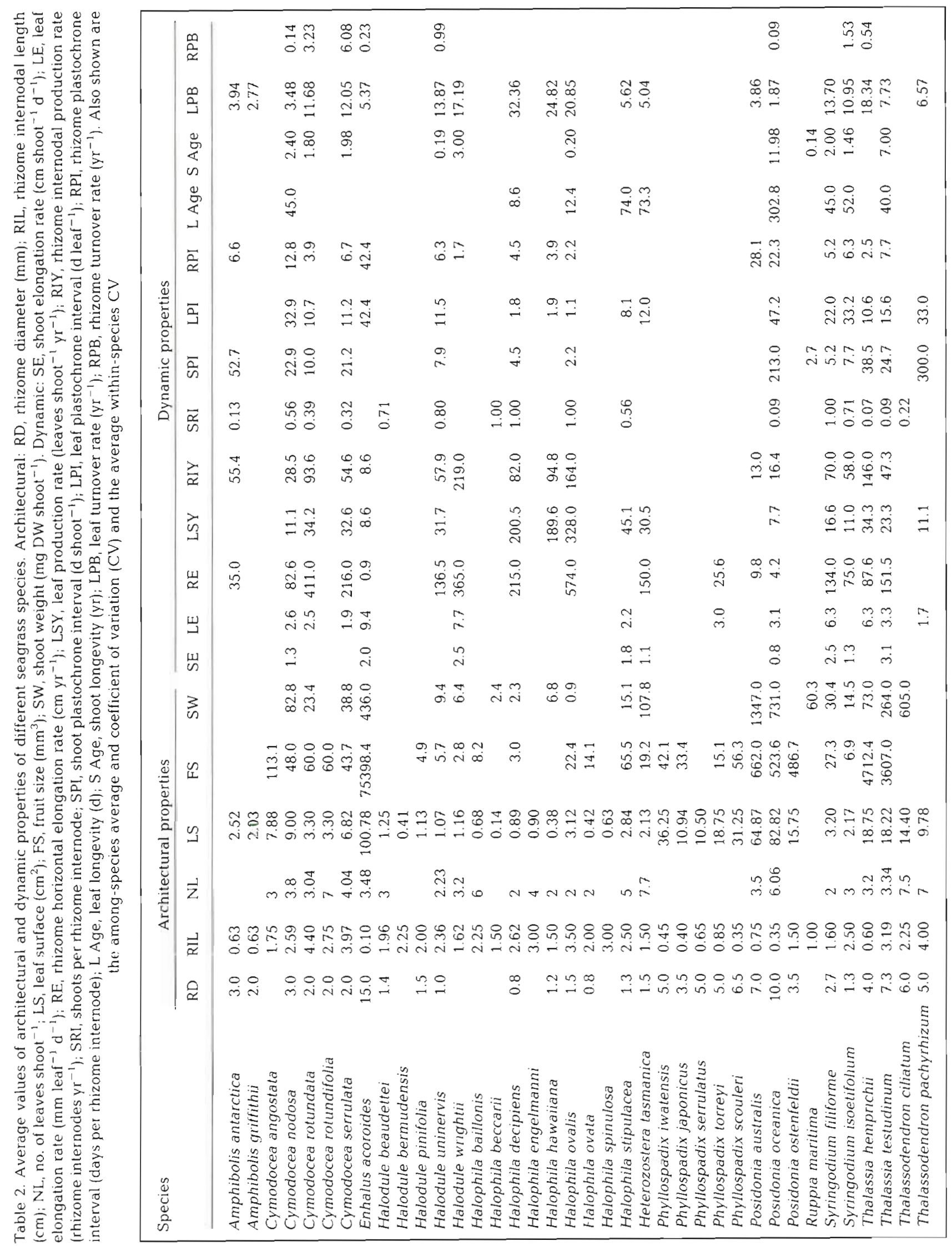




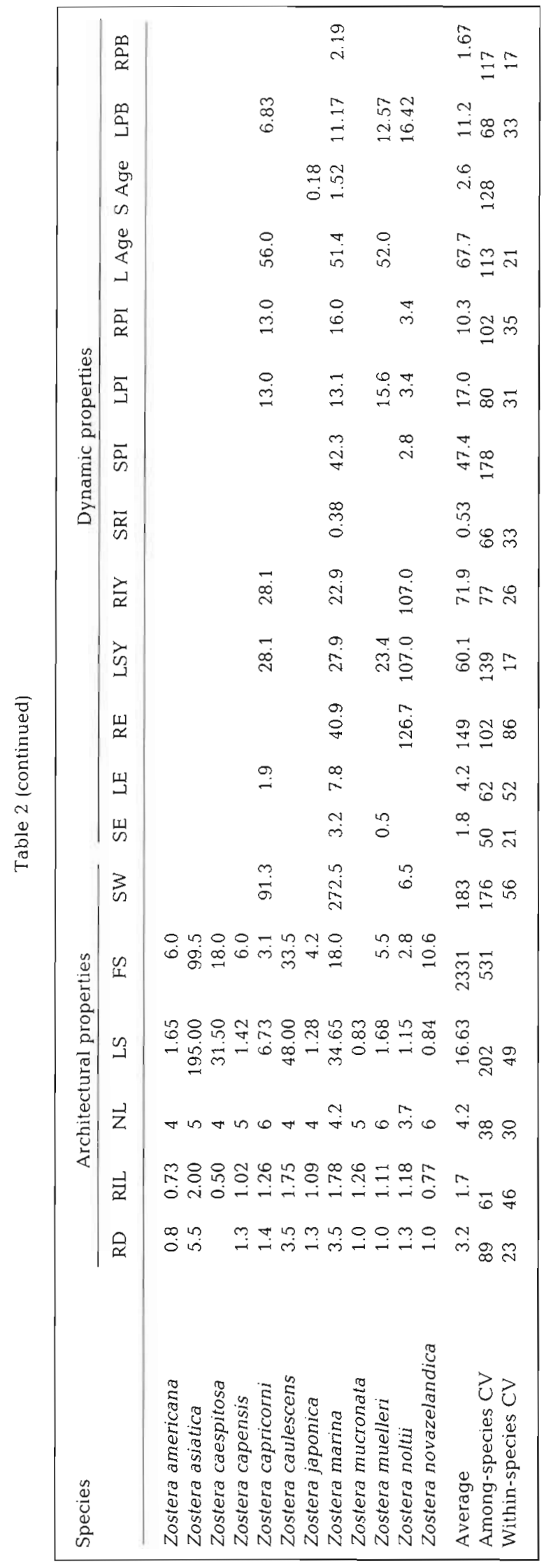

separated by more rhizome internodes than those of seagrasses with thin rhizomes. Rhizome diameter, however, characterizes the size of rhizome modules (i.e. rhizome internodes) only partially, for rhizome internodal length varied by a factor of 40 -fold among species (Table 2). However, the relationships between leaf and shoot size and the size of rhizome internodes were considerably weaker than those to rhizome diameter, for there was a weak, but significant trend for rhizome internodal length to be shorter in seagrass species with thick rhizomes $(r=-0.42, p<0.01)$.

\section{Allometric scaling of seagrass dynamics}

The hypothesis of size-dependence of seagrass dynamics was confirmed by the analyses, as demonstrated by the $1 / 2$ power scaling of the average time elapsed between emergence of consecutive leaves, shoots, and rhizome internodes (i.e. plastochrone intervals) to shoot weight (Eqs. 4 to 6 in Table 3; Fig. 2). Fast rates of leaf emergence in small seagrasses should result in rapid leaf turnover, as supported by the tendency of leaf turnover rates to decrease as (shoot size $)^{-1 / 3}$ (Eq. 7 in Table 3; Fig. 3).

Because plastochrone intervals reflect the biological age' of plants (Lamoreaux et al. 1978, Ritterbusch 1990), the long plastochrone intervals characteristic of modules of large seagrasses (Fig. 2) suggest that these may live longer than modules of small seagrasses. This contention was also confirmed by the tendency of leaf and shoot longevity to increase with increasing shoot size $(r=0.65$ and 0.56 respectively, $p<0.01)$. Scaling of shoot longevity to seagrass size was, however, stronger when plant size was represented by rhizome diameter (Eq. 8 in Table 3; Fig. 4) than when shoot size was used to represent seagrass size, probably because shoot size is subject to greater variability than rhizome diameter (Table 2). The plastochrone intervals (P.I.) and turnover rates (P/B: production/biomass, $\mathrm{yr}^{-1}$ ) of different seagrass modules were also strongly related to each other $\left(r_{\log l e a f}\right.$ P.I. vs $\log$ rhizome P.1. $=0.72, r_{\log \text { leaf } P / B \text { vs }}$ rhizome $\mathrm{P} / \mathrm{B}=0.74, \mathrm{p}<0.001 ;$ Fig. 5). Thus, species with fast leaf turnover rates and short plastochrone intervals also tend to have rapid rhizome turnover rates and short plastochrone intervals (Fig. 5), thereby reflecting a fundamental similarity in seagrass growth patterns. However, these relationships were not homogeneous, and seagrass species with fast rhizome turnover rates do not show any increase in leaf turnover rates with further increments in rhizome turnover rates (Fig. 5).

The elongation rate of seagrass leaves and shoots did not show any consistent pattern across species, and were poorly related ( $p>0.01$ ) to the size of either rhizomes or shoots. However, the horizontal elongation 
Table 3. Relationships between seagrass architecture and seagrass dynamics described by regression equations of the form $Y=$ $a X^{b} . \mathrm{N}$ represents the number of observations (i.e. seagrass species) included in the analysis. The strength of the relationships is characterized by the coefficient of determination $\left(R^{2}\right)$, their precision by the standard error of the (log-transformed) regression estimates ( $\left(\mathrm{E}_{\mathrm{log}}\right.$ est.), and the uncertainty about the regression slope is described by the standard error of the slope ( $\mathrm{SE}_{\mathrm{slope}}$ ). Units for architectural and dynamic properties as in Table 2. P.I.: plastochrone interval; P/B: production/biomass

\begin{tabular}{|c|c|c|c|c|c|c|c|c|}
\hline Eq. & $Y$ & $X$ & $a$ & $b$ & $\mathrm{R}^{2}$ & $\mathrm{~N}$ & $\mathrm{SE}_{\text {slope }}$ & $S E_{\log e s t}$ \\
\hline (1) & Leaf size & Rhizome diameter & -0.18 & 2.17 & 0.80 & 41 & 0.33 & 0.31 \\
\hline (2) & Shoot weight & Rhizome diameter & 0.72 & 2.57 & 0.68 & 20 & 0.31 & 0.49 \\
\hline (3) & Fruit size & Rhizome diameter & 0.56 & 2.91 & 0.61 & 33 & 0.32 & 0.63 \\
\hline (4) & Leaf P.I. & Shoot weight & 0.21 & 0.52 & 0.63 & 18 & 0.09 & 0.28 \\
\hline (5) & Shoot P.I. & Shoot weight & 0.02 & 0.73 & 0.65 & 14 & 0.11 & 0.33 \\
\hline (6) & Rhizome P.I. & Shoot weight & 1.22 & 0.44 & 0.63 & 18 & 0.09 & 0.28 \\
\hline (7) & Leaf $P / B$ & Shoot weight & 1.52 & -0.36 & 0.58 & 20 & 0.05 & 0.20 \\
\hline (8) & Shoot longevity & Rhizome diameter & -0.62 & 1.85 & 0.72 & 11 & 0.32 & 0.32 \\
\hline (9) & Rhizome elongation & Rhizome diameter & 2.03 & -0.47 & 0.59 & 18 & 0.30 & 0.45 \\
\hline$(10)$ & Rhizome elongation & Internodal length & 1.63 & 1.57 & 0.76 & 19 & 0.19 & 0.34 \\
\hline
\end{tabular}
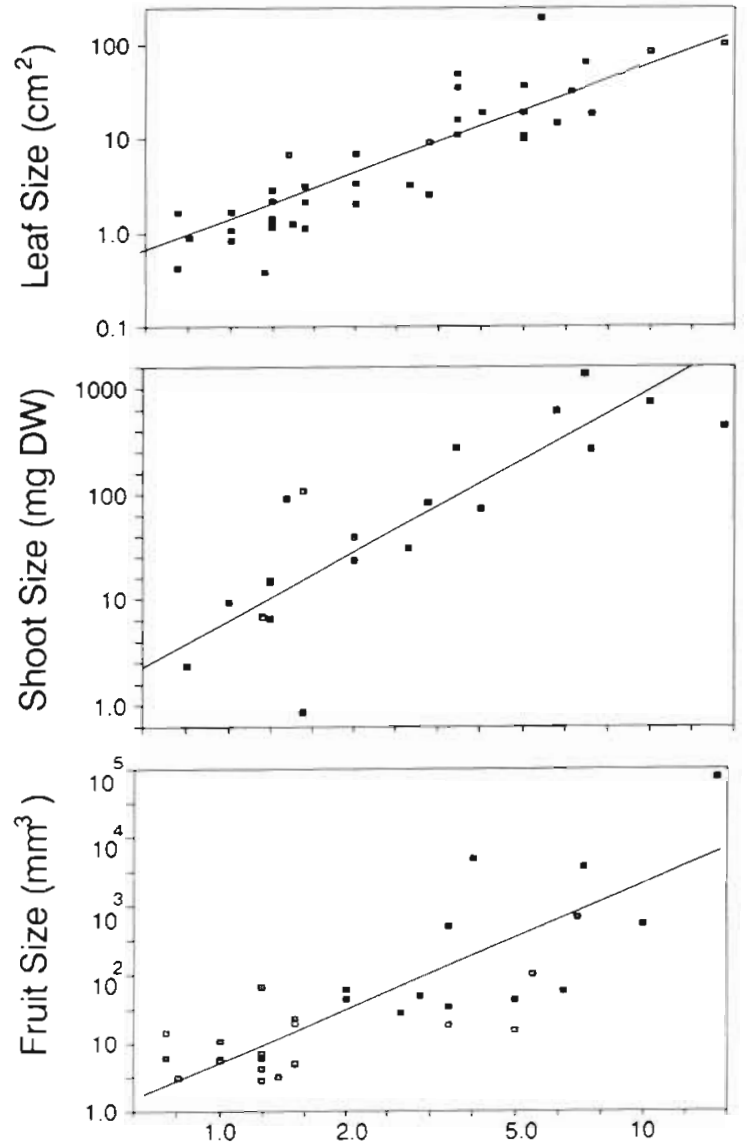

Rhizome diameter $(\mathrm{mm})$

Fig. 1 Relationships between leaf size, shoot size (DW dry wt), fruit size, and rhizome diameter Each data point represents the average values obtained for a different seagrass species

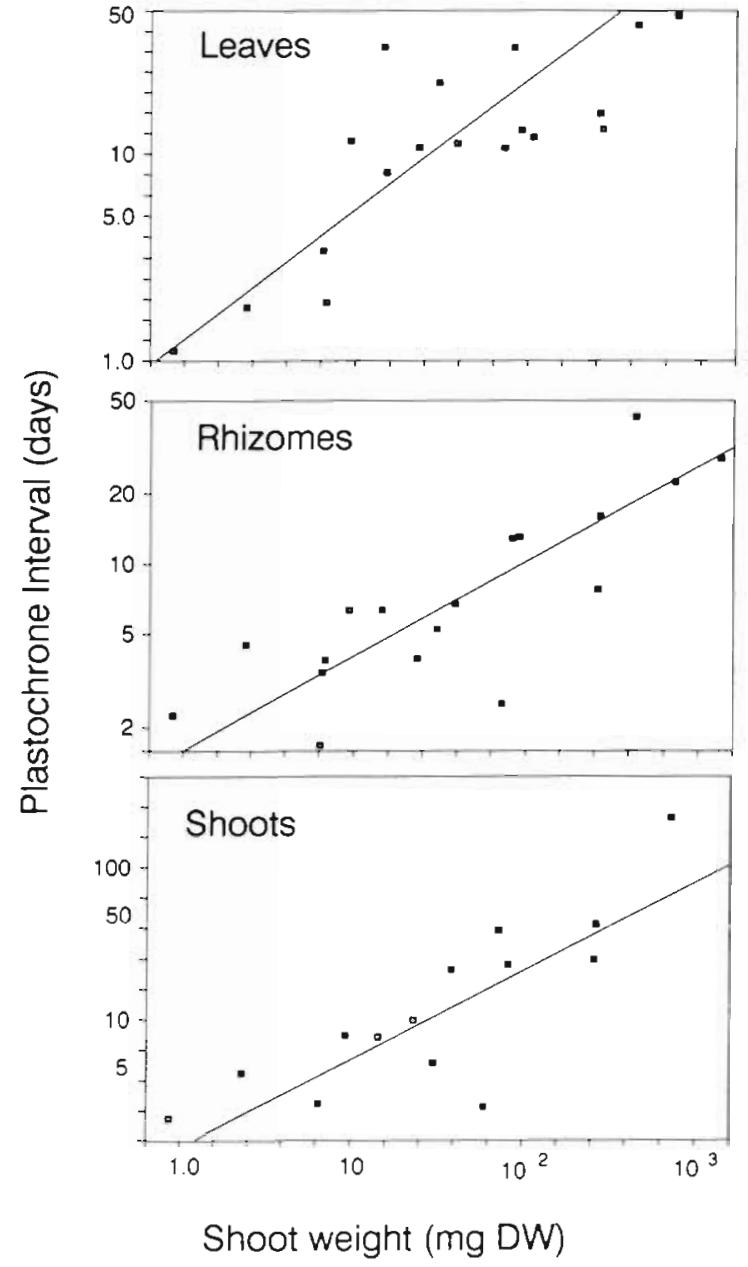

Fig. 2. Relationships between leaf, rhizome, and shoot plastochrone intervals (i.e. time elapsed between the appearance of 2 consecutive modules), and shoot weight 


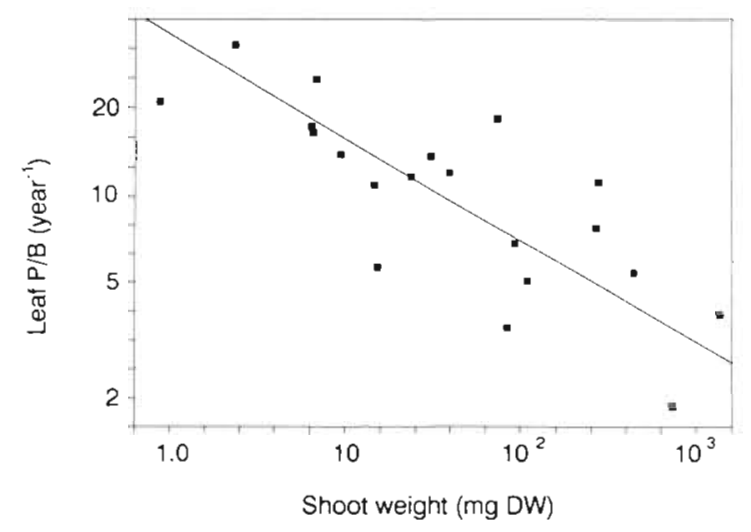

Fig. 3. Relationships between leaf turnover rate (P/B: production/biomass, $\mathrm{yr}^{-1}$ ) and shoot weight

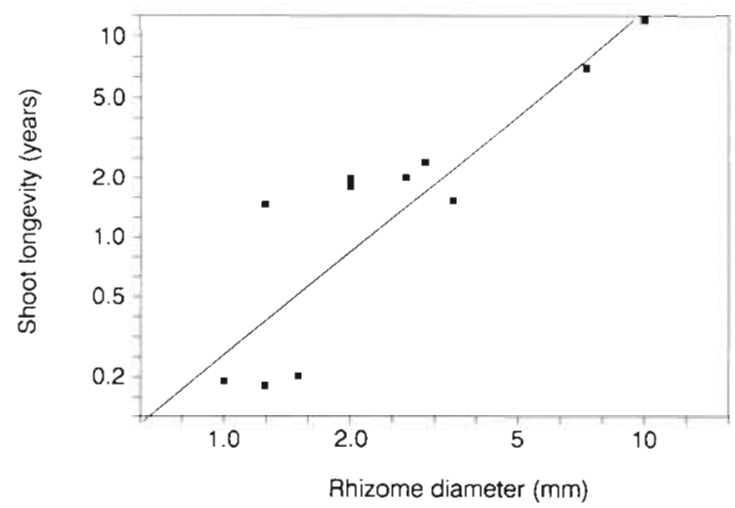

Fig. 4. Relationships between shoot longevity and rhizome diameter

rates of seagrass rhizomes were strongly related to the size of seagrass modules, and decreased with increasing rhizome diameter (Eq. 9 in Table 3; Fig. 6), but increased with increasing internodal length (Eq. 10 in Table 3; Fig. 6). Thus, a regression model including both rhizome diameter and internodal length,

$\log$ Rhizome elongation $\left(\mathrm{cm} \mathrm{yr}^{-1}\right)=$ $1.93-0.62 \log$ Rhizome diameter $(\mathrm{mm})+$

$1.14 \log$ Internodal length $(\mathrm{cm})$

$\left(\mathrm{R}^{2}=0.84, \mathrm{~N}=18, \mathrm{SE}_{\text {slope }}=0.26\right.$ and 0.22 i

$\mathrm{SE}_{\log \text { est. }}=0.28$,

accounted for most of the variability in rhizome elongation rates among seagrass species.

\section{DISCUSSION}

The data compiled here show that, because of their limited architectural repertoire, size differences (Table 2) play an important role in accounting for productivity
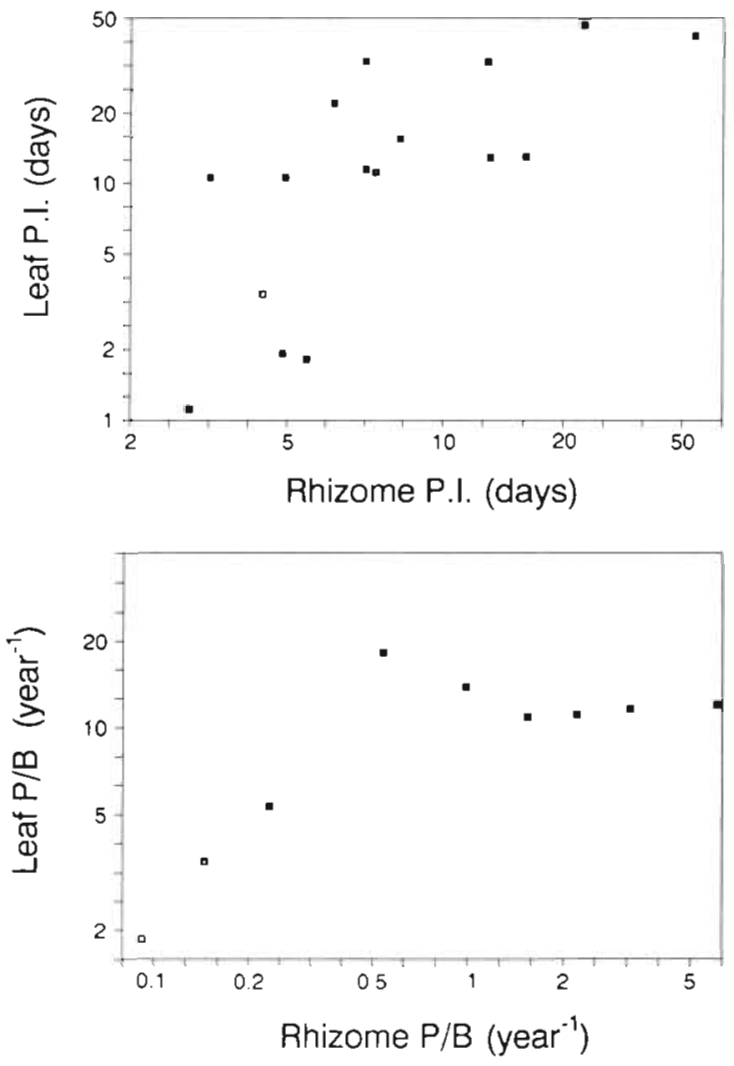

Fig. 5. Relationships between plastochrone intervals (P.I.) and turnover rates (P/B: production/biomass, $\mathrm{yr}^{-1}$ ) of seagrass leaves and rhizomes

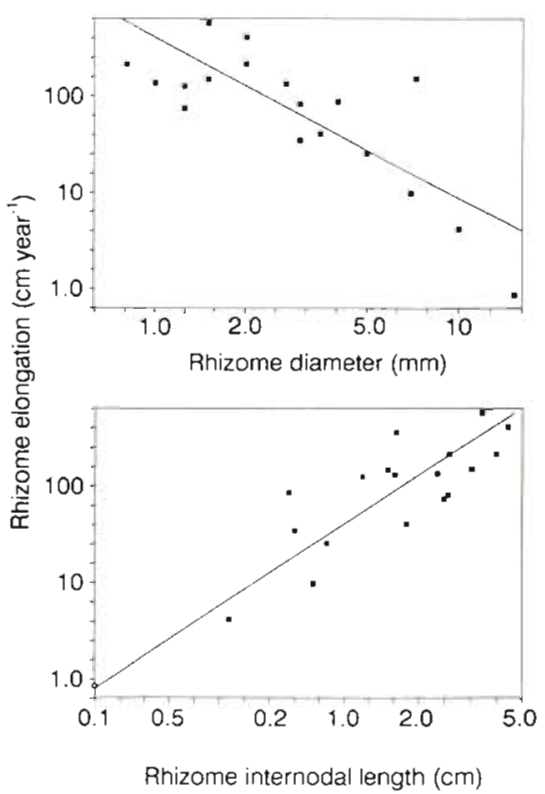

Fig. 6. Relationship between rhizome horizontal elongation rates and rhizome diameter and internodal length 
differences among seagrass species. Yet, withinspecies variability in some properties was found to be similar in magnitude to that among species. For instance, within-species variability in rhizome internodal length and number of leaves per shoot was similar in magnitude to among species variability, for both these properties are subject to strong seasonal variability, both showing minimum values in winter and peak values in mid-summer (e.g. Cayé \& Meinesz 1985, Kentula \& McIntire 1986, Duarte \& Sand-Jensen 1990). Similarly, leaf elongation rates, which are strongly seasonal and show considerable variability among populations of a given species (Zieman 1975, Thorhaug \& Roessler 1977, Bulthuis \& Woelkerling 1983), also varied almost as much within as among species (Table 2). Seasonal and habitat-dependence are also evident in other properties of seagrass, notably shoot and leaf size, leaf turnover rates and plastochrone intervals (e.g. Sand-Jensen 1975). Yet, among-species variability in these properties is larger than that within species (Table 2).

The strong relationships found among the sizes of different seagrass parts (Fig. 1, Table 3) provide evidence of the architectural similarity of seagrass species. These relationships, however, revealed differences in the relative increase in size of different seagrass components (Table 3). Rhizome diameter was found to be an appropriate factor for scaling the size of different seagrass modules, since the size of leaves, shoots, and fruits increased with increasing rhizome diameter among different species (Eqs. 1 to 3 in Table 3). In addition, within-species variation in rhizome size was found to be smaller than that in leaf or shoot size (Table 2), further demonstrating the use of rhizome diameter as a robust and useful descriptor of the architecture of seagrass species.

Rhizome diameter $(D)$ represents, in a pipe model of seagrass architecture (cf. Shinozaki et al. 1964), the width of the channels for substance transfer, which has a great influence on the volume rate of flow $(Q)$ along the channel (i.e. $Q \approx D^{4}$. Hagen-Poiseuille law; Bird et al. 1980). Thus, thick rhizomes should allow for a better integration among distant modules than in species with thinner rhizomes. Consequently, species with thick rhizomes should be able to gather the resources necessary to produce new shoots, leaves, and fruits from modules further apart than in species with thinner rhizomes, which should be more dependent on the resources available locally. The greater integration allowed by thick rhizomes, however, is achieved at the expense of a reduced potential for rhizome extension, and, thus, a limited colonizing capacity. Further, if seagrasses are likened to trees laid on their sides, as other rhizomatous plants have been (cf. Watt 1940, Harper 1977), the allometric rela- tionships of seagrass parts to rhizome diameter described here would be equivalent to those relating the size of terrestrial plants to stem diameter (e.g. Kittredge 1944, White 1981).

Differences in seagrass size had, as postulated, important implications for seagrass dynamics, for large seagrass species had slower tumover rates of leaves and rhizomes, and exhibited longer time lapses between the appearance of different modules (i.e. plastochrone intervals; Fig. 2), and longer-living leaves and shoots than did smaller species. Further, the -0.36 scaling of leaf $\mathrm{P} / \mathrm{B}$ ratios to shoot size (Eq. 7 in Table 3; Fig. 3) is similar to that described in the past for other field populations (Banse \& Mosher 1980). Although differences in leaf turnover and plastochrone intervals in leaves and rhizomes were found to be correlated, these relationships were not linear, for leaf turnover increases more slowly than rhizome turnover (Fig. 5). This implies that rapid rhizome tumover rates are achieved at the expense of reduced leaf turnover rates, and, consequently, a shift of resource allocation from leaf to rhizome growth.

Large seagrass species compensate their slower growth and turnover through extended life spans (Eq. 8 in Table 3; Fig. 4). Thus, large, long-living seagrasses are more productive - when productivity is scaled to their biological time (i.e. life span) - than are more ephemeral seagrasses, as demonstrated by significant positive correlations of the total production of leaves, rhizome internodes, and shoots during the life-span of a single shoot to shoot longevity $(r=0.78,0.55$ and 0.79 respectively, $\mathrm{p}<0.001)$. Further, shoots of some of the larger seagrass species develop flowers very rarely; for instance, shoots of Posidonia oceanica have been reported to flower, on average, once every 6 to $>50 \mathrm{yr}$ (Pergent \& Pergent-Martini 1990). However, these apparently small reproductive efforts may become, when computed over the extended shoot life spans of large seagrasses (Table 2), quite considerable. Moreover, since the total number of shoots and rhizome internodes produced along a rhizome axis during the life span of a shoot are also greater in the more longevous seagrass species, the reproductive effort of individual genets, which may appear small in natural time, may be quite phenomenal if computed during their life span, which is the relevant time frame for examining population dynamics.

The strong relationships between seagrass dynamics and size demonstrate the importance of architecture for seagrass productivity, and also provide explanations for the different ecological roles of small and large seagrass species. Small species are able to display the fast rhizome elongation rates and leaf turnover necessary to colonize new environments (Den Hartog 1977. Hillman et al. 1989). In contrast, large seagrass species 
are more longevous and their thicker rhizomes allow for a greater integration among modules, which permits the efficient use of resources necessary for the maintenance of long-lasting seagrass meadows in unproductive environments.

Size-differences among seagrass species, which constrain their ecological role, also determine the type of environments they may occupy. Small seagrass species may occupy frequently disturbed habitats, for they have the potential (e.g. fast rhizome elongation rates) to develop extensive populations and produce substantial amounts of organic carbon during the short time intervals between disturbances. Large seagrass species, however, require stable environments, which probably become even more stable when supporting a continuous seagrass cover, to develop similarly extensive and productive populations.

In summary, the results obtained demonstrate the importance of seagrass size as a constraint on the productivity and ecological strategies displayed by different seagrass species. These results also demonstrate that while habitat conditions, particularly light, temperature, and nutrients, play an important role in controlling seagrass productivity (e.g. Hillman et al. 1989), differences in the species composition of seagrass populations alone may involve order-ofmagnitude differences in productivity, depending on architectural differences among the species involved. Thus, the allometric relationships described here may provide, in the future, a basis for the prediction of species succession patterns and seagrass productivity from simple architectural characteristics of local floras.

Acknowledgements. I thank Kike Ballesteros for access to specimens of seagrass from the Caribbean and Indian Ocean, Kaj Sand-Jensen for stimulating discussion, and 2 anonymous reviewers for useful suggestions. This research was funded by a grant of the Fundación Ramón Areces.

\section{LITERATURE CITED}

Aioi, K. (1980). Seasonal changes in the standing crop of the eelgrass (Zostera marina L.) in Odawa Bay, central Japan. Aquat. Bot. 8: 343-354

Backman, T. W., Barilotti, D. C. (1976). Irradiance reduction: effects on standing crops of the eelgrass Zostera marina in a coastal lagoon. Mar. Biol. 34: 33-40

Bak, H. P. (1980). Age populations and biometrics in eelgrass, Zostera marina L. Ophelia 19: 155-162

Banse, K. Mosher, S. (1980). Adult body mass and annual production/biomass relationships of field populations. Ecol. Monogr. 50: 355-479

Barber, B. J., Beherens, P. J. (1985). Effects of elevated temperature on seasonal in situ leaf productivity of Thalassia testudinum Banks ex Konig and Syringodium filiforme Kutzing. Aquat. Bot. 22: 61-69

Bay, D. (1984). A field study of the growth dynamics and productivity of Posidonia oceanica (L.) Delile in Calvi Bay, Corsica. Aquat. Bot. 20: 43-64

Behdomme, A. L. (1981). Phénologie et production des feuilles de Posidonia oceanica (Linnaeus) Delile dans la Baie de Port-Cross: probeles methodologiques. M.Sc. thesis. Université d'Aix-Marseille II

Bigley, R. E., Harrison, P. G. (1986). Shoot demography and morphology of Zostera japonica and Ruppia maritima from British Columbia, Canada. Aquat. Bot. 24: 69-82

Bird, R. B., Stewart, W. E., Lightfoot, E. N. (1980). Transport phenomena. Wiley, New York

Bouderesque, C. F., Jeudy de Grissac, A., Meinesz, A. (1984). Relation entre la sédimentation et l'allongement des rhizomes orthotropes de Posidonia oceanica dans la Baie D'Elbu (Corse). In: Boudouresque, C. F., Jeudy de Grissac, A., Olivier, J. (eds.) Int. Workshop Posidonia beds. GIS Posidonie, Marseille, p. 185-191

Brouns, J. J. W. M. (1985). A comparison of the annual production and biomass in three monospecific stands of the seagrass Thalassia hemprichii (Ehrenb.) Achers. Aquat. Bot. 23: 149-175

Brouns, J. J. W. M. (1987). Growth patterns of some IndoWest-Pacific seagrasses. Aquat. Bot. 28: 39-61

Brouns, J. J. W. M., Heijs, F. M. L. (1986). Production and biomass of the seagrass Enhalus acoroides (L. f.) Royle and its epiphytes. Aquat. Bot. 25: 21-45

Buesa, R. (1974). Population and biological data on turtle grass (Thalassia testudinum Konig, 1805) on the Northwestern. Cuban Shelf. Aquaculture 4: 207-226

Buia, M. C., Cormaci, M., Furnari, G., Mazella, L. (1985) Osservazioni sulla strutura delle praterie di Posidonia oceanica (L.) Delile di Capo Passero (Siracusa) e studio della macroflora epifita delle foglie. Boll. Accad. Gioenia Sci. nat. 18: 463-484

Bulthuis, D. A. (1983). Effects of in situ light reduction on density and growth of the seagrass Heterozostera tasmanica (Martens ex Aschers.) den Hartog in Western Port, Victoria, Australia. J. exp. mar. Biol. Ecol. 67: 910-103.

Bulthuis, D. A., Woelkerling, Wm. J. (1983). Seasonal variation in standing crop, density, and leaf growth rate of the seagrass, Heterozostera tasmanica, in Western Port and Port Phillips Bay, Victoria, Australia. Aquat. Bot. 16: $111-136$

Cayé, G., Meinesz, A. (1985). Observations on the vegetative development, flowering and seeding of Cymodocea nodosa (Ucria) Ascherson on the Mediterranean coasts of France. Aquat. Bot. 22: 277-289

Clarke, S. M., Kirkman, H. (1989). Seagrass dynamics. In: Larkum, A. W. D., McComb, A. J., Shepherd, S. A. (eds.) Biology of seagrasses. A treatise on the biology of seagrasses with special reference to the Australian region. Elsevier, Amsterdam, p. 304-345

Clough, B. F., Attiwell, P. M. (1980). Primary production of Zostera muelleri Irmisch. ex Aschers. in Western Port Bay (Victoria, Australia). Aquat. Bot. 9: 1-13

Dawes, C. J., Tomasko, D. A. (1988). Depth distribution of Thalassia testudinum in two meadows on the west coast of Florida; a difference in effect of light availability. P.S.Z.N.I. Mar. Ecol. 9: 123-130

Den Hartog, C. (1970). The seagrasses of the world. North Holland Publ., Amsterdam

Den Hartog, C. (1977). Structure, function and classification in seagrass communities. In: McRoy, C. P., Helfferich, C. (eds.) Seagrass ecosystems: a scientific perspective. Marcel Dekker, New York, p. 89-121

Dennison, W. C., Alberte, R. S. (1985). Role of daily light 
period in the depth distribution of Zostera marina (eelgrass). Mar Ecol. Prog. Ser 25: 51-61

Duarte, C. M., Sand-Jensen, K. (1990). Seagrass colonization: biomass development and shoot demography in Cymodocea nodosa patches. Mar. Ecol. Prog. Ser. 67: 97-103

Eleuterius, L. N. (1987). Seagrass ecology along the coasts of Alabama, Louisiana, and Mississippi. In: Durako, M. J., Phillips, R. C., Lewis, R. R., III (eds.) Proc. Symp. subtropical-tropical seagrasses in the southeastern United States. Fla mar Res. Publs 42: 11-20

Estacion, J. S., Fortes, M. D. (1988). Growth rates and primary production of Enhalus acoroides (L. f.) Royle from Lag-it North Bais Bay, The Phillippines. Aquat. Bot. 29: 347-356

Fry, B. (1983). Leat growth in the seagrass Syringodium filiforme Kutz. Aquat. Bot. 16: 361-368

Fry, B., Virnstein. R. W (1988). Leaf production and export of the seagrass Syringodium filiforme Kutz. in Indian River lagoon, Florida. Aquat. Bot. 30: 261-266

Gambi, M. C. (1988). Flowering in a Zostera marina bed off San Juan Island (Washington, USA) during winter Aquat. Bot. 30: $267-272$

Gambi, M. C., Nowell, A. R. M., Jumars, P. A. (1990). Flume observations on flow dynamics in Zostera marina (eelgrass) beds. Mar. Ecol. Prog. Ser. 61. 159-169

Gil-Rodriguez, M. C., Cruz-Simó, M. C. (1982). Halophila decipiens Ostenfeld (Hidrocharitacae), una fanerogama marina nueva para el Atlantico oriental. Vieraea 11: $207-216$

Harper, J. L. (1977). Population biology of plants. Academic Press, London

Herbert, D. A. (1986). The growth dynamics of Halophila hawaiiana. Aquat. Bot. 23: 351-360

Hillman, K., Walker, D. I., Larkum, A. W. D., McComb, A. J (1989). Productivity and nutrient limitation. In: Larkum, A. W. D., McComb, A. J., Shepherd, S. A. (eds.) Biology of seagrasses. A treatise on the biology of seagrasses with special reference to the Australian region. Elsevier, Amsterdam, p. 635-685

Hulings, N. C. (1979). The ecology, biometry and biomass of the seagrass Halophila stipulacea along the Jordanian coast of the Gulf of Aqaba. Botanica mar 22: 425-430

Huxley, J. S. (1932). Problems of relative growth. Methuen \& Co., London

Ibarra-Obando, S. E., Huerta-Tamayo, R. (1987). Blade production of Zostera marina L during the summer-autumn period on the Pacific Coast of Mexico. Aquat. Bot. 28 : 301-315

Iverson, R. L., Bittaker, H. F. (1986). Seagrass distribution and abundance in eastern Gulf of Mexico coastal waters. Estuar coast. Shelf Sci. 22: 577-602

Jacobs, R. P. W. M. (1979). Distribution and aspects of the production and biomass of eelgrass, Zostera marina L. at Roscoff, France. Aquat. Bot. 7: 151-172

Jacobs, R. P. W. M. (1984). Biomass potential of eelgrass (Zostera marina L.). CRC critical Rev. Plant Scj. 2: 49-80

Jacobs, R. P. W M., Hegger, H. H., Ras-Willems, A. (1983a). Seasonal variations in the structure of a Zostera community on tidal flats in the SW Netherlands, with special reference to the benthic fauna. Proc. $K$ ned. Akad. Wet. (Sect. C) 86: 347--357

Jacobs, R. P. W. M., Noten, T M. P. A., Claassen, E. (1983b) Population and growth characeristics of the seagrass Zostra noltii Hornem. in the Dutch Wadden Sea. Proc. Int. Symp. on Aquatic Macrophytes, Nijmegen, The Netherlands. Catholic Univ., Nijmegen, p. 95-100

Johnstone, I. M. (1979). Papua New Guinea seagrasses and aspects of the biology and growth of Enhalus acoroides (L.f.) Royle. Aquat. Bot. 7: 197-208

Josselyn, M., Fonseca, M., Niesen, T., Larson, R. (1986). Biomass, production and decomposition of a deep water seagrass, Halophila decipiens Ostenf. Aquat. Bot. 25: 47-61

Keller, M., Harris, S. W. (1966). The growth of eelgrass in relation to tidal depth. J. Wildl. Mgmt 30: 280-285

Kentula, M. E., McIntire, C. D. (1986). The autoecology and production dynamics of eelgrass (Zostera marina L.) in Netarts Bay, Oregon. Estuaries 9: 188-199

Kenworthy, W. J., Currin, C. A., Fonseca, M. S., Smith, G (1989). Production, decomposition, and heterotrophic utilization of the seagrass Halophila decipiens in a submarine canyon. Mar. Ecol. Prog. Ser. 51: 277-290

Kerr, E. A., Strother, S. (1989). Seasonal changes in leat growth rate of Zostera muelleri Irmisch ex Aschers. in South-Eastern Australia. Aquat. Bot. 33: 131-140

Kirkman, H., Cook, I H. (1982). Biomass and growth of Zostera capricorni Aschers. in Port Hacking, N.S.W., Australia Aquat. Bot. 12: 57-67

Kirkman, H., Cook, I. H. (1987). Distribution and leaf growth of Thalassodendron pachyrhizum Den Hartog in Southern Western Australia. Aquat. Bot. 27: 257-266

Kurkman, H., Reid, D. D. (1979). A study of the role of the seagrass Posidonia australis in the carbon budget of an estuary. Aquat. Bot. 7: 173-183

Kittredge, J. (1944). Estimation of the amount of foliage of trees and shrubs. J. For. 42: 905-912

LaBarbera, N. (1989). Analyzing body size as a factor in ecology and evolution. A. Rev. Ecol. Syst. 20: 97-117

Lamoreaux, R. J., Chaney, W. R., Brown, K. M. (1978). The plastochrone index: a review after two decades of use. Am. J. Bot. 65: 586-593

Larkum, A. W. D. (1976). Ecology of Botany Bay. I. Growth of Posidonia australis (Brown) Hook. f. in Botany Bay and other Bays of the Sidney Basin. Aust. J. mar. Freshwat. Res. 27: $117-127$

Larkum, A. W. D., Collett, L. C., Williams, R. J. (1984). The standing stock, growth, and shoot production of Zostera capricorni Aschers. in Botany Bay, New South Wales, Australia. Aquat. Bot. 19: 307-327

Lipkin, Y. (1988). Thalassodendretum ciliati in Sinai (Northern Red Sea) with special reference to quantitative aspects. Aquat. Bot. 31: 125-139

Mukai, H., Aioi, K., Koike, I., Iizumi, J, Ohtsu, M., Hattori, A. (1979). Growth and organic production of eelgrass (Zostera marina L.) in temperate waters of the Pacific coast of Japan. 1. Growth analysis in spring-summer. Aquat. Bot. 7. $47-56$

Nienhuis, P. H., De Bree, B. H. H. (1980). Production and growth dynamics of eelgrass (Zostera marina) in brackish Lake Grevelingen (The Netherlands). Neth. J. Sea Res. 14: $102-118$

Ogden, J. C., Ogden, N. B. (1982). A preliminary study of two representative seagrass communities in Palau, Western Caroline Islands (Micronesia). Aquat. Bot. 12: 229-244

Ott, J. A. (1979). Persistence of a seasonal growth rhythm in Posidonia oceanica (L.) Delile under constant conditions of temperature and illumination. Mar Biol. Lett. 1 99-104

Ott, J. A. (1980). Growth and production in Posidonia oceanica (L.) Delile. P.S.Z.N.I. Mar. Ecol. 1:47-64

Patriquin, D. (1973). Estimation of growth rate, production and age of the marine angiosperm Thalassia testudinum König. Canbb. J. Sci. 13: 111-123

Pedersen, M. F. (1990). Production dynamics of eelgrass (Zostera marina L.). M.Sc thesis, University of Copenhagen 
Peduzzi, P., Vukovič, A. (1990). Primary production of Cymodocea nodosa in the Gulf of Trieste (Northern Adriatic Sea): a comparison of methods. Mar. Ecol. Prog. Ser 64: $197-207$

Perez, M. (1989). Fanerógamas marinas en sistemas estuáricos: producción, factores limitantes, y algunos aspectos del ciclo de nutrientes. Ph.D. thesis, Universidad de Barcelona

Perez, M., Romero, J., Duarte, C. M., Sand-Jensen, K. (1991). Phosphorus limitation of Cymodocea nodosa growth. Mar. Biol. 109: 129-133

Pergent, G., Pergent-Martini, C. (1990). Some applications of lepidochronological analysis in the seagrass Posidonia oceanica. Botanica mar 33: 299-310

Phillips, R. C., Santelices, B., Bravo, R, McRoy, C. P. (1983). Heterozostera tasmanica (Martens ex Aschers.) den Hartog in Chile. Aquat. Bot. 15: 195-200

Pirc, H. (1984). Depth-adaptation in Posidonia oceanica (L.) Delile. In: Boudouresque, C. F., Jeudy de Grissac, A., Olivier, J. (eds.) Int. Workshop Posidonia beds. GIS Posidonie, Marseille, p. 227-234

Ritterbusch, A. (1990). The measurement of biological age in plant modular systems. Acta biotheor 38: 113-124

Robertson, A. I., Mann, K. H. (1984). Disturbance by ice and life-history adaptations of the seagrass Zostera marina. Mar. Biol. 80: 131-141

Roman, C. T., Able, K. M. (1988). Production ecology of eelgrass (Zostera marina L.) in a Cape Cod salt marshestuarine system. Aquat. Bot. 32: 353-363

Romero-Martinengo, J. (1985). Estudio ecológico de las fanerógamas de la costa Catalana: producción primaria de Posidonia oceanica (L.) Delile en las Isalas Medes. Ph.D. thesis, Universidad de Barcelona

Sand-Jensen, K. (1975). Biomass, net production and growth dynamics in an eelgrass (Zostera marina L.) population in Vellerup Vig, Denmark. Ophelia 14: 185-201

Semround, R., Mezegrane, S., Soltane, L. (1990). Etude lepidochronologique de Posidonia oceanica dans la région d'Alger (Algérie) : donnes préliminaires. Rapp. Comm. int. Étude Mer Medit. 32 (B-I) : 15

Shinozaki, K., Yoda, K., Hozumi, K., Kira, T. (1964). A quantitative analysis of plant form - the pipe model theory. 1 Basis analyses. Jap. J. Ecol. 14: 97-105

Short, F. T. (1987). Effects of sediment nutrients on eelgrasses: literature review and mesocosms experiment. Aquat. Bot. 27: $41-57$

Short, F. T., Dennison, W. C., Capone, D. G. (1990). Phosphorus-limited growth of the tropical seagrass Syringodium filiforme in carbonate sediments. Mar Ecol. Prog. Ser. 62: 169-174

Silverstein, K. Chiffings, A. W., McComb, A. J. (1986). The loss of seagrass in Cockburn Sound, Western Australia. III. The effect of epiphytes on productivity of Posidonia australis Hook F. Aquat. Bot. 24: 355-371

Stevenson, J. C. (1988). Comparative ecology of submerged grass beds in freshwater, estuarine, and marine environments. Limnol. Oceanogr. 33: 867-893

Stewart, J. G. (1989). Maintenance of a balanced, shifting boundary between the seagrass Phyllospadix and algal turf. Aquat. Bot. 33: 223-241

Taylor, J. L., Saloman, C. H., Prest, K. W Jr (1973). Harvest and regrowth of turtle grass (Thalassia testudinum) in Tampa Bay, Florida. Fish. Bull. U.S. 71. 145-148

Thelin, I., Bouderesque, C. F. (1983). Longevité des teuilles de Posidonia oceanica dans un herbier superficiel de la Baie de Port-Cross (Var, France). Rapp. Comm. int. Étude Mer Medit. 28: 115-116
Thorhaug, A., Roessler, M. A. (1977). Seagrass community dynamics in a subtropical estuarine lagoon. Aquaculture 12: 253-277

Thorne-Miller, B., Harlin, M. M. (1984). The production of Zostera marina $\mathrm{L}$. and other submerged macrophytes in a coastal lagoon in Rhode Island, USA. Botanica mar 27: $539-546$

Till, R. (1974). Statistical methods for the earth scientist. An introduction. Macmillan, New York

Tomasko, D. A., Dawes, C. J. (1989). Evidence for physiological integration between shaded and unshaded short shoots of Thalassia testudinum. Mar. Ecol. Prog. Ser 54: 299-305

Tomasko, D. A., Dawes, C. J. (1990). Influences of season and water depth on the clonal biology of the seagrass Thalassia testudinum. Mar Biol. 105: 345-351

Tomlinson, P. B. (1974). Vegetative morphology and meristem dependence. The foundation of productivity in seagrasses. Aquaculture 4: 107-130

Tomlinson, P. B., Vargo, G. A. (1966). On the morphology and anatomy of turtle grass, Thalassia testudinum (Hydrocharitaceae). 1 Vegetative morphology. Bull. mar. Sci. 16: $748-761$

Umebayashi, O. (1988). Individual leaf growth of vegetative shoots of eelgrass, Zostera marina. Bull. Tokai reg. Fish. Res. Lab. 125: 1-13

Vermaat, J. E., Hootsman, M. J. M., Nienhuis, P. H. (1987). Seasonal dynamics and leaf growth of Zostera noltii Hornem., a perennial intertidal seagrass. Aquat. Bot. 28: $287-299$

Virnstein, R. W (1982). Leaf growth of the seagrass Halodule wrightii photographically measured in situ. Aquat. Bot. 12: 209-218

Wahbeh, M. I. (1984). The growth and production of the leaves of the seagrass Halophila stipulacea (Forsk.) Aschers. from Aqaba, Jordan. Aquat. Bot. 20: 33-41

Walker, D. I. (1989). Regional studies - Seagrass in Shark Bay, the foundations of an ecosystem. In: Larkum, A. W D., McComb, A. J., Shepherd, S. A. (eds.) Biology of seagrasses. A treatise on the biology of seagrasses with special reference to the Australian region. Elsevier, Amsterdam, p. $182-210$

Walker, D. I., McComb, A. J. (1988). Seasonal variation in the production, biomass, and nutrient status of Amphibolis antarctica (Labill.) Sonder ex Aschers. and Posidonia australis Hook. F. in Shark Bay, Western Australia. Aquat. Bot. 31. 259-275

Watt, A. S. (1940). Contributions to the ecology of bracken (Pteridium aquilinum). 1. The rhizome. New Phytol. 39: $401-422$

West, R. J. (1990). Depth-related structural and morphological variations in an Australian Posidonia seagrass bed. Aquat. Bot. 36: 153-166

West, R. J., Larkum, A. W. D. (1979). Leaf productivity of the seagrass, Posidonia australis, in Eastern Australian waters. Aquat. Bot. 7: 57-65

West, R. J., Larkum, A. W D., King, R. J. (1989). Regional studies - Seagrasses of South-Eastern Australia. In. Larkum, A. W. D., McComb, A. J., Shepherd, S. A. (eds.) Biology of seagrasses. A treatise on the biology of seagrasses with special reference to the Australian region. Elsevier, Amsterdam, p. 230-260

White, J. (1981). The allometric interpretation of the shelfthinning rule. J. theor Biol. 89: 475-500

Williams, S. L. (1987). Competition between the seagrasses Thalassia testudinum and Syringodium filiforme in a Caribbean lagoon. Mar. Ecol. Prog. Ser. 35: 91-98 
Williams, S. L. (1988). Thalassia testudinum productivity and grazing by green turtles in a highly disturbed seagrass bed. Mar Biol. 98: 447-455

Wittmann, K. J. (1984). Temporal and morphological variations of growth in a natural stand of Posidonia oceanica (L.) Delile. P.S.Z.N.I. Mar. Ecol. 5: 301-316

This article was presented by G. W. Thayer, Beaufort, N. Carolina, USA
Zieman, J. C. (1975). Seasonal variation of turtle grass, Thalassia testudinum Konig, with reference to temperature and salinity effects. Aquat. Bot. 1. 107-123

Zieman, J. C., Fourqurean, J. W., Iverson, R. L. (1984). Distribution, abundance, and productivity of seagrasses and macroalgae in Florida Bay. Bull. mar. Sci. 44: 292-311

Manuscript first received: March 19, 1991 Revised version accepted: September 17, 1991 